\title{
AN ASSESSMENT OF MANAGEMENT HISTORY OF DAMAGED AND UNDAMAGED TREES 8 YEARS AFTER THE ICE STORM IN ROCHESTER, NEW YORK, U.S.
}

\author{
by Wayne C. Zipperer', Susan M. Sisinni², Jerry Bond ${ }^{3}$, Chris Luley4, and Andrew \\ G. Pleninger 5
}

\begin{abstract}
Eight years of post-storm tree maintenance records from Rochester, New York, U.S., were reviewed to evaluate the city's storm-related removal protocol and how maintenance varied by damage classes. Maintenance codes assigned in 1991 were used to identify ice-storm damage classes based on percentage of crown loss. We evaluated seven species-Norway maple (Acer platanoides), silver maple (A. saccharinum), sugar maple (A. saccharum), green ash (Fraxinus pennsylvanica), honeylocust (Gleditsia triacanthos), London planetree (Platanus $\times$ acerifolia), and littleleaf linden (Tilia cordata)—to assess species responses to maintenance protocols. Trees with $75 \%$ or more crown loss and undamaged trees required the least amount of maintenance, additional management, and on-site re-evaluation. In contrast, trees with $50 \%$ to $75 \%$ crown loss required the most maintenance, were the greatest percentage of trees requiring additional maintenance, and were the most revisited. Of the selected species analyzed, silver maple and honeylocust required the most maintenance, whereas sugar maple, green ash, and littleleaf linden required the least. Across all damage classes and species, maintenance requirements increased with tree diameter at breast height regardless of the percentage of crown loss or species.
\end{abstract}

Key Words. Ice-storm damage; maintenance; species; crown; diameter

In March 1991, a severe ice storm blanketed 19 counties in western New York, U.S., resulting in more than US\$40 million in damage to urban trees in Rochester. For a description of the storm and ice-storm history, see Sisinni et al. (1995).

Immediately following the storm, the city contracted an inventory of all public trees to assess storm damage based on a visual estimation of the percentage of crown loss. The following damage categories were used: removal 1 (R1), $75 \%$ or more crown loss or major limb breakage into the trunk heartwood; removal 2 (R2), 50\% to 75\% crown loss; corrective pruning (CP), less than 50\% crown loss; and undamaged trees (UD).

Despite the frequency and costs of ice-storm damage to urban trees, formal criteria do not exist for post-storm maintenance decisions. In Rochester, initial decisions were based entirely on the percentage of crown loss. Following the storm, the city forester developed a restoration plan to address tree removals, pruning, and planting. Based on this plan, trees that sustained more than $50 \%$ crown loss were scheduled for removal because they potentially require frequent and costly long-term maintenance, expose the remaining urban forest population to insect and disease infestations, or threaten people and property.

The first priority for storm-damage management was to remove R1s and R2s located along the city's highly traveled arterial and collector streets (completed summer 1991). Next priority was the removal of Rls located on residential streets (completed winter 1991/92). Though all R1s were scheduled for removal, some were left at the request of residents. Because it was recognized that crown loss does not adequately predict tree response and survival, the remaining $\mathrm{R} 2$ trees were re-evaluated using a more detailed risk evaluation based on species, individual tree condition and age, and site location. Re-evaluated R2s with low scores were removed. Unfortunately, individual scores were not recorded. CP trees usually were not removed because it was believed that they were not hazardous, would survive with minimal maintenance, and provide benefits to city residents. The objective of this study was to evaluate post-storm maintenance by damage class, tree species, and diameter class to determine efficacy of management decisions.

\section{METHODS \\ Study Site}

Rochester is in Monroe County in western New York, approximately $112.7 \mathrm{~km}$ (70 mi) east-northeast of Buffalo and $9.7 \mathrm{~km}(6 \mathrm{mi})$ south of Lake Ontario. It is the third largest city in the state, occupying $96 \mathrm{~km}^{2}\left(37 \mathrm{mi}^{2}\right)$, with a population density of approximately $2,400 / \mathrm{km}^{2}\left(6,200 / \mathrm{mi}^{2}\right)$. Rochester rests on the Erie-Ontario Lake Plain, which has a nearly level to gently sloping topography and an elevation of about $171 \mathrm{~m}$ (561 ft). Rochester's climate is humid-continental with warm summers and long, cold winters. The city is in or near the path of most major weather systems moving across the continent or up the Atlantic Coast. This results in varied 
seasonable weather from year to year. Lakes Erie and Ontario influence local climate by moderating temperatures throughout the year and producing frequent, heavy snowfall in winter (Heffner and Goodman 1973).

\section{Relative Management}

By cross-referencing the 1991 and 1998 street tree databases, we identified the remaining storm-damaged trees (R1s, R2s, and CPs) and those trees that had no storm damage (UDs). Because each public tree had a record of current and past maintenance, work histories were reviewed to compare relative types and frequency of poststorm maintenance required by the three damage classes and seven species-Norway maple (Acer platanoides), silver maple (A. saccharinum), sugar maple (A. saccharum), green ash (Fraxinus pennsylvanica), honeylocust (Gleditsia triacanthos), London planetree (Platanus $\times$ acerifolia), and littleleaf linden (Tilia cordata). Individually, each species accounted for at least $5 \%$ of the total street tree population. Species that represented less than 5\% were grouped into a single category called Other. Insufficient information exists to examine individual cultivars. Hence, cultivars within a species are considered one species. Finally, five diameter (diameter at breast height, dbh) classes-less than $25 \mathrm{~cm}$ (< 10 in.), 26 to $47 \mathrm{~cm}$ (10 to 18.4 in.), 48 to $70 \mathrm{~cm}$ (18.5 to 274 in.), 71 to $92 \mathrm{~cm}$ (27.5 to 36.4 in.), and greater than 92 $\mathrm{cm}$ (> 36.4 in.) — were used to evaluate the relationship between tree size and maintenance needs. Maintenance categories included total number of trees maintained, number of trees that had more than one maintenance visit recorded, maintenance time per tree per visit, and number of service requests from property owners. Maintenance time represented actual work time on the tree. Unless work was done on a tree, service requests and maintenance visits were not included in maintenance time. Because of the changes in recording maintenance time, we used only those records from 1991 to 1995 to evaluate how maintenance time varied by damage class and species. Costs were not evaluated because insufficient information existed to accurately estimate expenses.

\section{Statistical Analyses}

All remaining R1s and R2s were evaluated. Because parametric values for the R1s and R2s were known for the entire population, traditional statistical evaluation, based on a sample population, was not appropriate. The measured differences for these maintenance classes are the actual differences.

For CPs and UDs, a stratified random sample was drawn from their subpopulation following procedures for categorical (multi-state) variables outlined by Cochran (1977). From the database of R1s, R2s, CPs, and UDs, we evaluated species responses. Sample size varied by species and damage class, and reflected a standard error of $5 \%$. Because of different sample sizes, reported values were standardized by number of trees analyzed.

To identify differences among maintenance categories, we used a Student's t-test for two variables and a general linear model for three or more variables with Duncan's multiple range test to separate means with an $\alpha=0.05$ (Zar 1974). Statistical analyses were conducted using SAS version 8.1 (SAS 2000). For percentage of trees maintained and percentage of trees revisited, observed values are reported.

\section{RESULTS}

Maintenance records for 3,241 trees were reviewed to identify differences in the number of trees maintained, the number trees revisited, maintenance time, and number of service requests by damage class and species (Table 1). For selected species, Norway maple represented the largest sample portion (25.5\%) and sugar maple represented the smallest (7.2\%) (Table 1).

Mean maintenance time per tree increased between 1991 and 1995 (Figure 1). After 1995, it declined because of changes in management protocol. A comparison of years between 1991 and 1995 showed that in 1991, a tree required a mean of 0.2 hours to maintain. By 1994, the mean had significantly increased to 1.7 hours and reached 2.1 hours in 1995 (mean square 25.7920, F value 19.55, P < 0.0001).

\section{Damage Class}

Evaluation of the diameter distribution of the damage classes showed that $77.2 \%, 90.5 \%$, and $88.9 \%$ of R1s, R2s, and CPs, respectively, were larger than $25 \mathrm{~cm}$ (10 in.) dbh (Table 2). In contrast, only $51.2 \%$ of UDs were larger than $25 \mathrm{~cm}$ (10 in.) dbh. These differences are especially important with respect to maintenance time per tree because larger trees require more maintenance time (Figure 2). A

Table 1. Number of trees sampled by damage class and species.

\begin{tabular}{|c|c|c|c|c|c|c|c|c|c|}
\hline \multirow[b]{2}{*}{ Damage class } & \multicolumn{7}{|c|}{ Species } & \multirow[b]{2}{*}{ Other } & \multirow[b]{2}{*}{ All stems } \\
\hline & $\begin{array}{l}\text { Norway } \\
\text { maple }\end{array}$ & $\begin{array}{l}\text { Silver } \\
\text { maple }\end{array}$ & $\begin{array}{l}\text { Sugar } \\
\text { maple }\end{array}$ & $\begin{array}{l}\text { Green } \\
\text { ash }\end{array}$ & $\begin{array}{l}\text { Honey- } \\
\text { locust }\end{array}$ & $\begin{array}{l}\text { London } \\
\text { planetree }\end{array}$ & $\begin{array}{l}\text { Littleleaf } \\
\text { linden }\end{array}$ & & \\
\hline Removal 1 (R1) & 24 & 7 & 2 & 12 & 17 & 7 & 4 & 19 & 92 \\
\hline Removal 2 (R2) & 446 & 219 & 22 & 211 & 219 & 121 & 133 & 312 & 1,683 \\
\hline Corrective pruning (CP) & 94 & 90 & 77 & 75 & 94 & 91 & 88 & 105 & 714 \\
\hline Undamaged (UD) & 111 & 58 & 89 & 91 & 100 & 60 & 87 & 156 & 752 \\
\hline
\end{tabular}


Table 2. Diameter distribution by damage classes.

\begin{tabular}{|c|c|c|c|c|c|c|}
\hline \multirow[b]{2}{*}{ Damage class } & \multicolumn{5}{|c|}{ Diameter class (cm dbh) } & \multirow[b]{2}{*}{ All stems } \\
\hline & $<25$ & $25-47$ & $48-70$ & $71-92$ & $>92$ & \\
\hline Removal 1 (R1) & $\begin{array}{l}21 \\
(22.8 \%)\end{array}$ & $\begin{array}{l}42 \\
(45.7 \%)\end{array}$ & $\begin{array}{l}16 \\
(17.4 \%)\end{array}$ & $\begin{array}{l}11 \\
(12.0 \%)\end{array}$ & $\begin{array}{l}2 \\
(2.2 \%)\end{array}$ & 92 \\
\hline Removal 2 (R2) & $\begin{array}{l}160 \\
(9.5 \%)\end{array}$ & $\begin{array}{l}668 \\
(39.7 \%)\end{array}$ & $\begin{array}{l}572 \\
(34.0 \%)\end{array}$ & $\begin{array}{l}208 \\
(12.4 \%)\end{array}$ & $\begin{array}{l}75 \\
(4.5 \%)\end{array}$ & 1,683 \\
\hline Corrective pruning $(\mathrm{CP})$ & $\begin{array}{l}79 \\
(11.1 \%)\end{array}$ & $\begin{array}{l}327 \\
(45.8 \%)\end{array}$ & $\begin{array}{l}190 \\
(26.6 \%)\end{array}$ & $\begin{array}{l}81 \\
(11.3 \%)\end{array}$ & $\begin{array}{l}37 \\
(5.2 \%)\end{array}$ & 714 \\
\hline Undamaged (UD) & $\begin{array}{l}367 \\
(48.8 \%)\end{array}$ & $\begin{array}{l}343 \\
(45.6 \%)\end{array}$ & $\begin{array}{l}28 \\
(3.7 \%)\end{array}$ & $\begin{array}{l}10 \\
(1.3 \%)\end{array}$ & $\begin{array}{l}4 \\
(0.5 \%)\end{array}$ & 752 \\
\hline All stems & $\begin{array}{l}627 \\
(19.4 \%)\end{array}$ & $\begin{array}{l}1,380 \\
(42.6 \%)\end{array}$ & $\begin{array}{l}806 \\
(24.9 \%)\end{array}$ & $\begin{array}{l}310 \\
(9.6 \%)\end{array}$ & $\begin{array}{l}118 \\
(3.6 \%)\end{array}$ & 3,241 \\
\hline
\end{tabular}

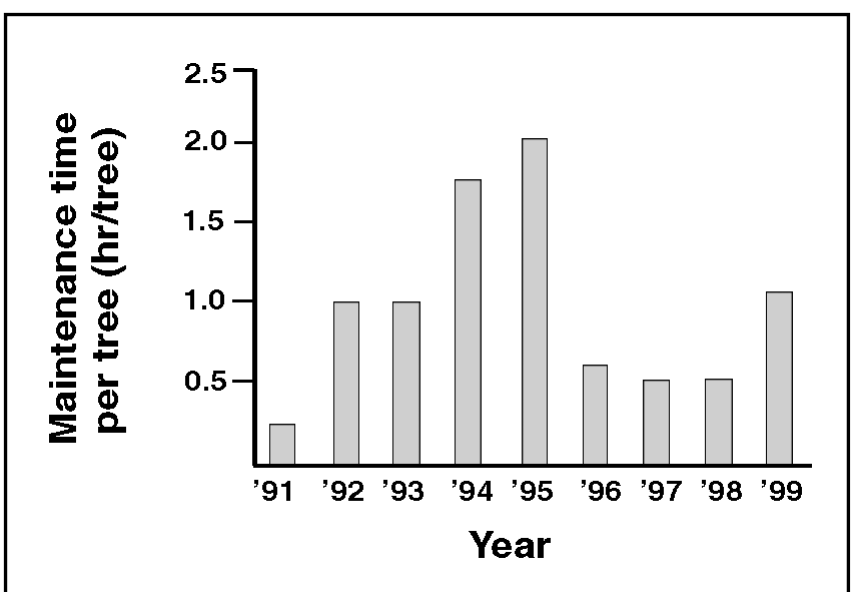

Figure 1. Maintenance time per tree by year.

comparison of diameter classes showed that each successive class required significantly more time to maintain than the next smaller class (mean square 211.3577, F value 131.65, $\mathrm{P}<0.001$ ).

More than $80 \%$ of all trees, regardless of damage class, required maintenance between 1991 and 1998 (Figure 3). R2s and CPs had a greater proportion of the sample population requiring maintenance and repeat visits. R1s and UDs had similar numbers of trees maintained and repeat maintenance visits. A distinct pattern was observed for service requests (Figure 3). The number of requests declined from R1s to UDs and indicated a pattern that showed as storm-related crown loss decreased, so did the number of service requests.

A comparison of damage classes across all diameter classes showed a difference in mean maintenance time (Table 3). R2s required the most time to maintain ( 1.7 hours per tree), and UDs required the least amount of time (0.9 hours per tree). R2s require 10 minutes more per tree to maintain than Rls. Individually, this difference was small, but cumulatively, it could be substantial within a given year. Similarly, overall CPs required significantly more time to

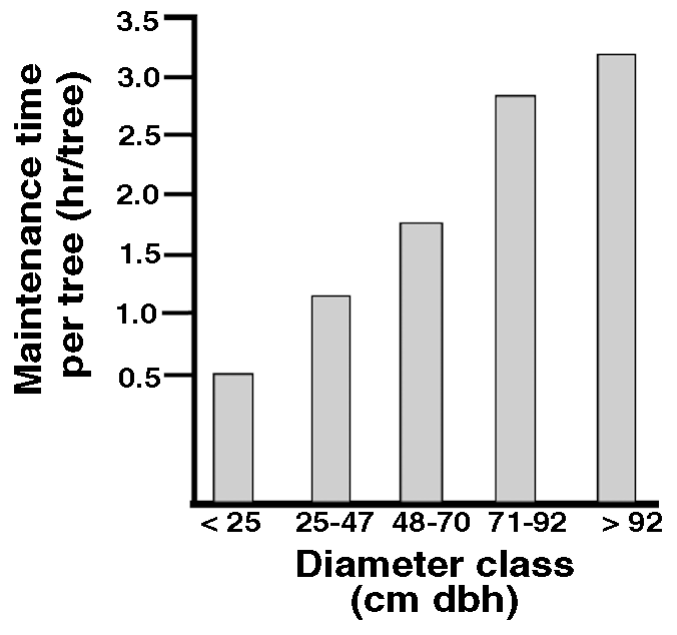

Figure 2. Maintenance time per tree by diameter class for the period between 1991 and 1995.

maintain than UDs $(\mathrm{P}<0.001)$, but maintenance time per tree by diameter was similar for CPs and UDs (Table 3). In general, R1s and R2s required more time to manage than CPs and UDs. Plus, the combination of damage and diameter classes was a better indicator of management need than either class individually.

\section{Species Response}

Species can be divided into two groups based on diameter distributions: those with a high proportion of individuals in the small-diameter classes and those with a proportion of individuals in the large classes (Table 4). For silver maples, $76 \%$ of the sample population had diameters larger than 47 cm (18.4 in.) dbh. By comparison, sugar maple, green ash, honeylocust, and littleleaf linden had less than $27 \%$ of individuals larger than $47 \mathrm{~cm}$ (18.4 in.) dbh. Norway maple and London planetree had more balanced distributions with $53 \%$ and $43 \%$, respectively. 
For individual species, the observed patterns of the portion of individual trees maintained, service requests, and repeat visits were similar to those observed for the damage classes (Figure 4). In general, species with the highest proportion of R2s and CPs had the highest proportion of

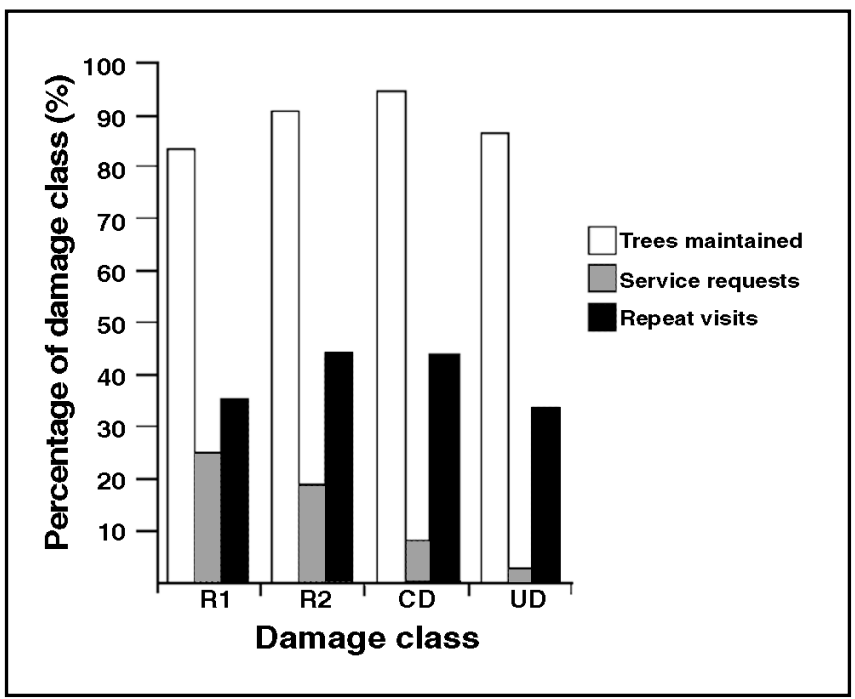

Figure 3. Proportion of the sample population by damage class for trees maintained, service requests, and repeat visits. (See text for description of damage classes.)

Table 3: Mean maintenance time per tree (hours) ( \pm s.e.) from 1991 to 1995 by damage and diameter classes.

\begin{tabular}{lllllll}
\hline & \multicolumn{5}{c}{ Diameter class (cm dbh) } & All stems \\
\cline { 2 - 6 } Damage class & $<25$ & $25-47$ & $48-70$ & $71-92$ & $>92$ & 1.5 \\
\hline Removal 1 (R1) & 0.4 & 1.4 & 1.1 & 2.8 & 4.2 & 1.7 \\
Removal 2 (R2) & 0.6 & 1.1 & 1.9 & 2.6 & 3.7 & $1.4 \pm 0.1^{*}$ \\
Corrective pruning (CP) & $0.5 \pm 0.1$ & $1.1 \pm 0.1$ & $1.7 \pm 0.2^{1}$ & $2.5 \pm 0.3^{2}$ & $2.4 \pm 0.4^{12}$ & 1.4 \\
Undamaged (UD) & $0.5 \pm 0.1$ & $1.0 \pm 0.1$ & $1.8 \pm 0.3^{1}$ & $2.2 \pm 0.4^{1}$ & $2.1 \pm 0.5^{1}$ & $0.9 \pm 0.1$ \\
\hline
\end{tabular}

${ }^{*} \mathrm{CP}$ is significantly different from UD at $\mathrm{P}<0.05$.

${ }^{1,2}$ Statistically similar among diameter classes within a damage class, $\mathrm{P}>0.05$.

Table 4. Diameter distribution of a sample population of selected tree species.

\begin{tabular}{|c|c|c|c|c|c|c|}
\hline \multirow[b]{2}{*}{ Damage class } & \multicolumn{5}{|c|}{ Diameter class (cm dbh) } & \multirow[b]{2}{*}{ All stems } \\
\hline & $\overline{<25}$ & $25-47$ & $48-70$ & $71-92$ & $>92$ & \\
\hline Silver maple & $\begin{array}{l}45 \\
(12.0 \%)\end{array}$ & $\begin{array}{l}43 \\
(11.5 \%)\end{array}$ & $\begin{array}{l}79 \\
(21.1 \%)\end{array}$ & $\begin{array}{l}136 \\
(36.4 \%)\end{array}$ & $\begin{array}{l}71 \\
(19.0 \%)\end{array}$ & 374 \\
\hline London planetree & $\begin{array}{l}36 \\
(12.9 \%)\end{array}$ & $\begin{array}{l}109 \\
(39.1 \%)\end{array}$ & $\begin{array}{l}63 \\
(22.6 \%)\end{array}$ & $\begin{array}{l}47 \\
(16.8 \%)\end{array}$ & $\begin{array}{l}24 \\
(8.6 \%)\end{array}$ & 279 \\
\hline Norway maple & $\begin{array}{l}63 \\
(9.3 \%)\end{array}$ & $\begin{array}{l}253 \\
(37.5 \%)\end{array}$ & $\begin{array}{l}287 \\
(42.5 \%)\end{array}$ & $\begin{array}{l}67 \\
(9.9 \%)\end{array}$ & $\begin{array}{l}5 \\
(0.7 \%)\end{array}$ & 675 \\
\hline Sugar maple & $\begin{array}{l}45 \\
(23.7 \%)\end{array}$ & $\begin{array}{l}109 \\
(57.4 \%)\end{array}$ & $\begin{array}{l}26 \\
(13.7 \%)\end{array}$ & $\begin{array}{l}9 \\
(4.7 \%)\end{array}$ & $\begin{array}{l}1 \\
(0.5 \%)\end{array}$ & 190 \\
\hline Green ash & $\begin{array}{l}137 \\
(35.0 \%)\end{array}$ & $\begin{array}{l}182 \\
(46.8 \%)\end{array}$ & $\begin{array}{l}64 \\
(16.5 \%)\end{array}$ & $\begin{array}{l}6 \\
(1.5 \%)\end{array}$ & & 389 \\
\hline Honeylocust & $\begin{array}{l}96 \\
(22.3 \%)\end{array}$ & $\begin{array}{l}220 \\
(51.2 \%)\end{array}$ & $\begin{array}{l}108 \\
(25.1 \%)\end{array}$ & $\begin{array}{l}6 \\
(1.4 \%)\end{array}$ & & 430 \\
\hline Littleleaf linden & $\begin{array}{l}79 \\
(25.3 \%)\end{array}$ & $\begin{array}{l}179 \\
(57.4 \%)\end{array}$ & $\begin{array}{l}51 \\
(16.3 \%)\end{array}$ & $\begin{array}{l}3 \\
(1.0 \%)\end{array}$ & & 312 \\
\hline
\end{tabular}

their population maintained and requiring repeated visits. The notable differences were sugar maple and littleleaf linden in the service requests analysis. This difference was attributed to small sample sizes - two and four trees, respectively, in the $\mathrm{R} 1$ damage class (Table 1 ).

Differences in maintenance requirements were observed among species (Tables 5 and 6). Silver maple required the most time per tree to maintain $(\mathrm{P}<0.001)$. $\mathrm{R} 1$ silver maples required an average of 2.3 hours more per tree than UD silver maples. $\mathrm{CP}$ silver maples required significantly more time to maintain than UD silver maples $(\mathrm{P}<0.05)$. Within a damage class, the largest difference in maintenance time was 3.1 hours between silver maple and littleleaf linden for R1s. With the exception of silver maple, R2s required more time to maintain for a species than the other damage classes. Honeylocust also showed high maintenance need for CPs and was significantly different from green ash $(\mathrm{P}<0.001)$ (Table 5).

Overall, species did not differ within the smaller-diameter classes [ $<48 \mathrm{~cm}$ (18.5 in.)] for maintenance, but with the exception of littleleaf linden, maintenance times varied significantly among species in the larger diameter (Table 6). For all species, regardless of damage and diameter classes, silver maple required the most time to maintain. In contrast, green ash, sugar maple, and littleleaf linden required the least time to maintain $(1.0,1.0$, and 1.1 hours per tree, respectively) (Table 6). Regardless of species, tree size significantly affected maintenance time.

\section{DIscussion}

In a previous paper (Sisinni et al. 1995), data from a comprehensive public tree survey identified responses of urban trees to severe ice accumulation. Trees requiring corrective pruning (CP) were not included in the analysis because they had such a wide range of damage ( $1 \%$ to $49 \%$ crown loss). Few conclusions could be drawn about the direct impacts of ice on individual species. At that time, the Rochester city forester predicted that R1s and R2s were so severely damaged that they were terminal or would be too costly and labor-intensive to maintain. On the other hand, CPs were considered able to survive long enough, with minimal added maintenance, to provide an acceptable cost-benefit ratio to city residents. 


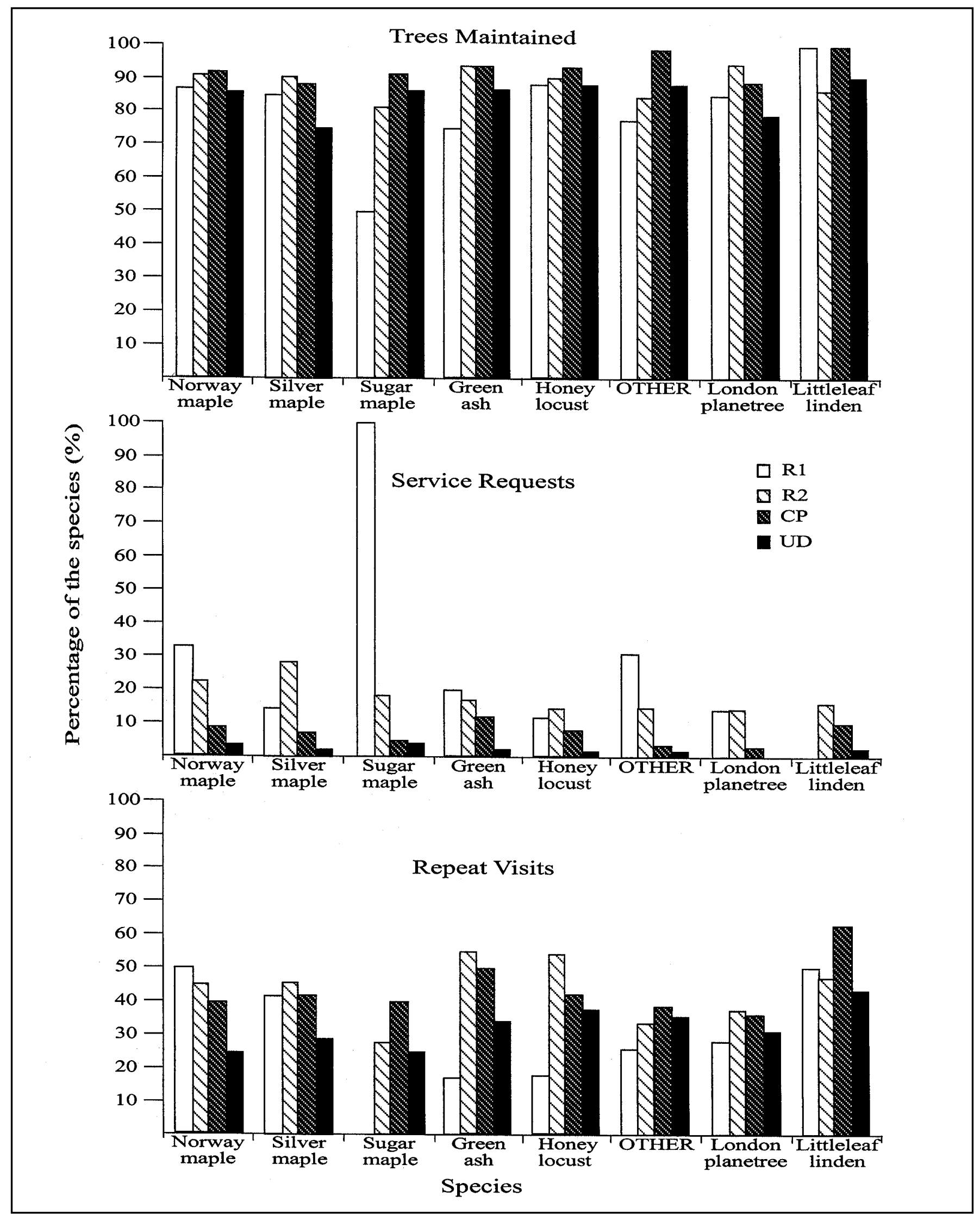

Figure 4. Proportion of sample trees by damage classes and individual species for trees maintained, service requests, and repeat visits. (See text for description of damage classes.) 
Table 5. Mean maintenance time per tree (hours) ( \pm s.e.) from 1991 to 1995 by species and damage class.

\begin{tabular}{lllll}
\hline & \multicolumn{4}{c}{ Damage class } \\
\cline { 2 - 5 } Species & Removal 1 & Removal 2 & Corrective pruning & Undamaged \\
\hline Silver maple & 3.5 & 2.9 & $2.3 \pm 0.3^{\mathrm{bl}}$ & $1.2 \pm 0.3^{\mathrm{b}}$ \\
Norway maple & 1.2 & 1.5 & $1.3 \pm 0.2^{\mathrm{a}}$ & $1.1 \pm 0.2^{\mathrm{ab}}$ \\
London planetree & 1.3 & 1.7 & $1.3 \pm 0.2^{\mathrm{a}}$ & $0.8 \pm 0.2^{\mathrm{ab}}$ \\
Sugar maple & 0.0 & 0.9 & $1.2 \pm 0.2^{\mathrm{a}}$ & $0.9 \pm 0.1^{\mathrm{ab}}$ \\
Green ash & 1.0 & 1.2 & $0.83 \pm 0.1^{\mathrm{a}}$ & $0.5 \pm 0.1^{\mathrm{a}}$ \\
Honeylocust & 1.4 & 1.6 & $1.9 \pm 0.3^{\mathrm{bl}}$ & $1.0 \pm 0.2^{\mathrm{ab}}$ \\
Littleleaf linden & 0.4 & 1.3 & $1.1 \pm 0.1^{\mathrm{a}}$ & $0.8 \pm 0.08^{\mathrm{ab}}$ \\
\hline${ }^{\mathrm{a}, \mathrm{b}, \mathrm{c}, \mathrm{C}}$ Statistically similar among species in a column, $\mathrm{P}>0.05$. & \\
${ }^{1}$ Significantly different from UD at $\mathrm{P}<0.05$. &
\end{tabular}

Table 6. Mean maintenance time (hours) ( \pm s.e.) by selected species and diameter class.

\begin{tabular}{|c|c|c|c|c|c|c|}
\hline \multirow[b]{2}{*}{ Damage class } & \multicolumn{4}{|c|}{ Diameter class (cm dbh) } & \multirow[b]{2}{*}{$>92$} & \multirow[b]{2}{*}{ All stems } \\
\hline & $<25$ & $25-47$ & $48-70$ & $71-92$ & & \\
\hline Silver maple & $0.3 \pm 0.1^{\mathrm{al}}$ & $1.3 \pm 0.2^{\mathrm{al}}$ & $1.9 \pm 0.2^{\mathrm{abl}}$ & $3.1 \pm 0.2^{\mathrm{b} 2}$ & $3.5 \pm 0.4^{a 2}$ & $2.5 \pm 0.1^{c}$ \\
\hline Norway maple & $0.4 \pm 0.1^{\mathrm{a}}$ & $1.1 \pm 0.1^{\mathrm{a}}$ & $1.6 \pm 0.1^{\mathrm{al}}$ & $1.8 \pm 0.2^{\mathrm{al}}$ & $4.8 \pm 1.7^{\mathrm{a}}$ & $1.4 \pm 0.1^{b}$ \\
\hline London planetree & $0.6 \pm 0.1^{\mathrm{al}}$ & $1.1 \pm 0 . .^{\text {la12 }}$ & $1.8 \pm 0.1^{\mathrm{ab} 23}$ & $3.0 \pm 0.3^{\mathrm{ab} 4}$ & $2.0 \pm 0.8^{\mathrm{a} 1234}$ & $1.4 \pm 0.1^{\mathrm{ab}}$ \\
\hline Sugar maple & $0.5 \pm 0.1^{\mathrm{al}}$ & $0.9 \pm 0.1^{\text {al2 }}$ & $1.4 \pm 0.3^{\mathrm{ab} 2}$ & $2.6 \pm 0.73^{\mathrm{ab}}$ & 5.0 & $1.0 \pm 0.1^{\mathrm{ab}}$ \\
\hline Green ash & $0.5 \pm 0.04^{\mathrm{al}}$ & $1.0 \pm 0.04^{\mathrm{a} 2}$ & $2.1 \pm 0.1^{\mathrm{ab} 3}$ & $1.2 \pm 0.3^{\mathrm{ab} 123}$ & 0.0 & $1.0 \pm 0.1^{\mathrm{a}}$ \\
\hline Honeylocust & $0.6 \pm 0.1^{\mathrm{al}}$ & $1.3 \pm 0.1^{\mathrm{al}}$ & $2.5 \pm 0.3^{\mathrm{b} 2}$ & $3.3 \pm 2.1^{\mathrm{ab} 2}$ & 0.0 & $1.5 \pm 0.1^{\mathrm{b}}$ \\
\hline Littleleaf linden & $0.5 \pm 0.1^{\mathrm{a}}$ & $1.1 \pm 0.1^{\mathrm{a}}$ & $1.8 \pm 0.2^{\mathrm{ab}}$ & 4.3 & 0.0 & $1.1 \pm 0.1^{\mathrm{ab}}$ \\
\hline All stems & $0.5 \pm 0.04$ & $1.1 \pm 0.04$ & $1.8 \pm 0.1$ & $2.6 \pm 0.2$ & $3.2 \pm 0.3$ & $1.4 \pm 0.03$ \\
\hline
\end{tabular}

a,b,c Statistically similar among species in a column, $\mathrm{P}>0.05$

$1,2,3,4$ Statistically similar among diameter classes within a species, $\mathrm{P}>0.05$.

\section{Damage Classes}

The post-storm maintenance analysis seems to support the prediction for R2s but not for R1s. Though more than $75 \%$ of the crown had been removed, Rls had a post-storm maintenance need similar to UDs for number of trees maintained and repeat visits and to CPs for maintenance time per tree. However, these numbers may not reflect the actual work required by $\mathrm{R} 1$ trees. Most of the remaining $\mathrm{R} 1$ trees were left standing pending a signed waiver transferring future maintenance and liability responsibilities from the city to the property owner. Nevertheless, even with this agreement, city work crews performed most maintenance.

Analysis of the diameter classes showed that Rls required the most time to manage in three of the five diameter classes -25 to $47 \mathrm{~cm}$ (10 to $18.4 \mathrm{in}$.), 48 to $70 \mathrm{~cm}$ (28.5 to 36.4 in.), and $>92 \mathrm{~cm}$ (36.4 in.) dbh. Rls also had the highest percentage for service requests. Apparently, the reduced crown size may have highlighted maintenance needs to citizens. R1s ultimately may require the most management needs as decay from large cuts occurs in the remaining branches and the trunk.

Maintenance needs for R2s supported our prediction. R2s had a high number of trees maintained, a high frequency of both service requests and repeat visits, and the highest mean maintenance time per tree. These findings might be related more to the percentage of trees (56\%) within the damage class in the large-diameter classes ( $>47$ $\mathrm{cm}$ (18.4 in.) dbh). No other damage class had a similar distribution. When comparing mean maintenance time per tree for the individual diameter classes, R2s had a mean time similar to CPs and UDs in the smaller classes but higher a mean time in the larger-diameter classes.

Surprisingly, CPs required the most maintenance of the storm-damage classes. They had a higher proportion of trees managed, a higher frequency of site requests and repeat visits, and a higher mean maintenance time per tree than UDs. Intuitively, trees with crown losses greater than $30 \%$ should require more care than those with less than 30\% (sensu Shortle and Smith 1998). Unfortunately, we do not know the extent of individual crown losses. However, based on the percentage of trees (43.1\%) in the largediameter classes, we might expect a high frequency of trees with moderate damage, thus requiring more maintenance. When we compare the mean maintenance times of the individual diameter classes, CPs and UDs were not statistically different; however, from a manager's perspective, CPs required more time to maintain with more trees in the larger-diameter classes. 
The observed differences in management needs of Rls, R2s, CPs, and UDs are associated with initial storm damage and size of tree. Across damage classes, smaller-diameter trees had similar mean maintenance time per tree, and larger-diameter trees principally had significantly different mean maintenance times. However, even in the largediameter classes, UDs required less time to maintain and had the least service requests.

\section{Species Response}

In Sisinni et al. (1995), we reported on responses of individual species to a catastrophic ice storm in Rochester, New York. Species susceptible to ice-storm damage included Japanese pagoda (Sophora japonica), green ash, silver maple, London planetree, callery pear (Pyrus calleryana), and Norway maple. Of these species, we examined only green ash, silver maple, London planetree, and Norway maple in this paper. We added sugar maple, honeylocust, and littleleaf linden because of their relative density with respect to the entire tree population. Based on mean maintenance times, species can be placed in one of three maintenance categories following ice-storm damage: extensive management (silver maple and honeylocust), moderate management (Norway maple and London planetree), and minimal management (sugar maple, green ash, and littleleaf linden).

Silver maple, regardless of damage class, had the greatest mean maintenance time of all species (2.5 hours per tree). $\mathrm{R} 1$ silver maples required the most time and UDs the least. Silver maple has been identified as a problematic species in urban areas because of its weak crotches and wood, which increases its susceptibility to wind and ice damage (Rogers 1923; Croxton 1939; Hauer et al. 1993). High mean maintenance times might be related to tree size [76\% of the sample was $>47 \mathrm{~cm}$ (18.4 in.)] and the extent of prior maintenance. Mean maintenance times for silver maple were significantly different from other species for trees greater than $47 \mathrm{~cm}$ dbh. Silver maple actually had lower mean maintenance times than the other species in the smallerdiameter classes. The urban forester needs to weigh the benefits of silver maple against the cost of management (Richards 1993; Sisinni et al. 1995).

Honeylocust, a popular urban tree, previously was listed as moderately susceptible to ice-storm damage (Sisinni et al. 1995). In the current analysis, honeylocust had the second highest mean maintenance time ( 1.5 hours per tree) of all the species. It ranked second to silver maple for mean maintenance times for R1s, R2s, and CPs. In silver maple , a high mean maintenance time was associated with a high percentage trees in larger diameter classes. For honeylocust, $73 \%$ of sampled trees were smaller than $48 \mathrm{~cm}$ (19 in.) dbh and 54\% were classified as R1s and R2s. Green ash also had a high proportion of R1s and R2s (57\%) but a low percentage of large stems (18\%). Green ash, however, had one of the lowest mean maintenance times of all the species. Our analyses indicated that honeylocust required significantly more maintenance for its diameter distribution when compared with other species with a similar distribution.

Norway maple and London planetree showed moderate susceptibility to ice-storm damage (Sisinni et al. 1995) and had moderately high mean maintenance times. Both species had a mean maintenance time of 1.4 hours per tree. This value was significantly lower than values observed for silver maple but higher than those observed for sugar maple, green ash, and littleleaf linden. Like silver maple, Norway maple and London planetree were not significantly different from the other species in the smaller-diameter classes but had higher values in the larger classes. Although these values were not statistically significant, their pattern indicates more maintenance. For Norway maple, the higher values in the larger diameters may be attributed to high percentage of trees in the larger-diameter classes [ $52 \%$ of sampled trees were greater than $47 \mathrm{~cm}$ (18.4 in.) dbh and $70 \%$ classified as R1s and R2s]. Likewise, London planetree had $48 \%$ of sampled trees larger than $47 \mathrm{~cm}$ dbh and $46 \%$ were classified as R1s and R2s.

\section{CONCLUSION}

In the eastern United States, urban forest managers will need to decide which damaged trees to keep or remove after an ice storm. Removal decisions often are based on the extent of crown damage. Analysis of management requirements from the March 1991 ice storm in Rochester indicate that crown damage, although a good indicator of future performance, needs to be combined with species type and tree size before an effective decision on removal can be made. Our analyses indicate that a species can be placed into one of three maintenance requirement categories-high, moderate, or low-after sustaining ice-storm damage. In addition, within a species, tree size plays an important role in determining future management requirement. Largerdiameter trees will require more maintenance than smallerdiameter trees with the same extent of crown damage. Although we did not evaluate site conditions and history, these factors should also be factored into the decisionmaking process. For example, species planted off site should perform poorly after sustaining crown damage and may require more maintenance. Regardless of crown damage, species and tree size, public safety will ultimately determine if a tree is removed. 


\section{LITERATURE CITED}

Cochran, W.G. 1977. Sampling Techniques. John Wiley and Sons, New York, NY. 428 pp.

Croxton, W.C. 1939. A study of the tolerance of trees to breakage by ice accumulation. Ecology 20:71-73.

Hauer, R.J., W. Wang, and J.O. Dawson. 1993. Ice storm damage to urban trees. J. Arboric. 19:187-193.

Heffner, R.C., and S.D. Goodman. 1973. Soil Survey of Monroe County, New York. USDA Soil Conservation Service, in cooperation with Cornell University Agricultural Experiment Station, Washington, DC. 172 pp.

Richards, R.A. 1993. Reasonable guidelines for street tree diversity. J. Arboric. 19:344-349.

Rogers, W.E. 1923. Resistance of trees to ice storm injury. Bull. Torr. Bot. Club 88:21-29.

SAS. 2000. SAS/STAT User's Guide, Version 8, Volumes 1, 2 , and 3. SAS Publishing, Cary, NC. 3,845 pp.

Shortle, W., and K. Smith. 1998. How To Determine Percent Live Crown Loss in Hardwoods Before Leaf-Out. Information Sheet \#1. USDA Forest Service, Durham, NH. 2 pp.

Sisinni, S.M., W.C. Zipperer, and A.G. Pleninger. 1995. Impacts from a major ice storm: Street-tree damage in Rochester, New York. J. Arboric. 21:156-165.

Zar, J.H. 1974. Biological Analysis. Prentice-Hall, Inc., Englewood Cliffs, NJ. 620 pp.
${ }^{1 *}$ USDA Forest Service

clo SUNY ESF

5 Moon Library

Syracuse, NY 13210, U.S.

2202 Crawford Avenue

Syracuse, NY 13224, U.S.

${ }^{3}$ Davey Resource Group

3904 Willowdale Lane

Geneva, NY 14456, U.S.

${ }^{4}$ Davey Tree

'6050 Hicks Road

Naples, NY 14512, U.S.

${ }^{5}$ Urban Forestry LLC

176 Elmcroft Road

Rochester, NY 14609, U.S.

*Corresponding author. 
Résumé. Huit années de données sur le post-entretien des arbres endommagés par une tempête à Rochester dans l'état de New York ont été revues, et ce afin d'évaluer le protocole de la ville relativement à l'abattage des arbres endommagés par la tempête, et aussi afin de voir comment l'entretien varie selon le degré de dommages survenus. Les codes d'entretien assignés en 1991 ont été employés pour identifier les classes de dommages par le verglas en se basant sur le pourcentage de perte de cime. Sept espèces ont été évaluées-érable de Norvège (Acer platanoides), érable argenté (Acer saccharinum), érable à sucre (Acer saccharum), frêne rouge (Fraxinus pennsylvanica), févier (Gleditsia triacanthos), platane (Platanus x acerifolia) et tilleul à petites feuilles (Tilia cordata)—afin de déterminer la réponse des espèces aux protocoles d'entretien. Les arbres avec 75\% ou plus de perte de cime, ainsi que ceux non endommagés, ont requis les plus faibles montants pour leur entretien et comptaient la plus faible quantité de sujets nécessitant une gestion additionnelle ou une re-évaluation sur le site. Par contraste, les arbres ayant de 50 à $75 \%$ de perte de cime ont requis le plus d'entretien et comptaient la plus forte proportion de sujets nécessitant un entretien additionnel et une réinspection. Des espèces sélectionnées qui ont été analysées, l'érable argenté et le févier ont requis le plus d'entretien tandis que l'érable à sucre, le frêne rouge et le tilleul à petites feuilles en ont requis le moins. Au sein de toutes les classes de dommages et des espèces, les besoins en entretien augmentaient avec l'accroissement en diamètre au DHP, et ce peu importe le pourcentage de perte ou l'espèce.

Zusammenfassung. Acht Jahre Aufzeichnungen über Aufräumarbeiten nach Sturmereignissen aus Rochester, New York, wurden durchgesehen, um die Baumentfernungsprotokolle und die Pflege während unterschiedlicher Schadensstufen auszuwerten. Die 1991 festgesetzten Pflegemaßnahmen wurden benutzt, um Eissturmschadensklassen auf prozentualen Kronenverlust zu identifizieren. Wir schätzten sieben Arten: Acer platanoides, A. saccharum, A. saccharinum, Fraxinus excelsior, Gleditsia triacanthos, Platanus x acerifolia und Tilia cordata in ihrer Reaktion auf die Pflege. Bäume mit 75 \% oder mehr Kronenverlust und unbesch- ädigte Bäume erforderten den geringsten Pflegeaufwand und hatten den geringsten Anteil an zusätzlichem Pflegebedarf und Standortabhängige Bewertung. Im Gegensatz dazu verlangten Bäume mit 50-75 \% Kronenverlust die meiste Pflege, hatten den größten Anteil an Nachsorge und die meisten nachuntersuchten Bäume. Von den analysierten ausgewählten Arten verlangten A. saccharinum und G. triacanthos die meiste Pflege und Zuckerahorn, grüne Esche und Winterlinde die wenigste. Über allen Schadensklassen nahm der Pflegeaufwand mit ansteigendem BHD zu, unabhängig vom Prozentsatz des Kronenverlusts oder Art.

Resumen. Se revisaron ocho años de registros de mantenimiento post-tormenta en Rochester, New York, para evaluar el protocolo de remoción en la ciudad y cómo el mantenimiento varió por clase de daño. Los códigos de mantenimiento asignado en 1991 fueron usados para identificar las clases de daño por tormenta de hielo con base en pérdidas de por ciento de copa. Evaluamos siete especies Norway maple (Acer platanoides), silver maple (A. saccharinum), sugar maple (A. saccharum), green ash (Fraxinus pennsylvanica), honeylocust (Gleditsia triacanthos), London planetree (Platanus x acerifolia) y littleleaf linden (Tilia cordata) — con el fin de medir la respuesta de las especies a los protocolos de mantenimiento. Los árboles con 75 por ciento o más de pérdida de copa y los árboles sin daño requirieron la menor cantidad de mantenimiento y tuvieron menos ejemplares requiriendo mantenimiento adicional y reevaluación en el sitio. En contraste, los árboles con 50 a $75 \%$ de pérdida de copa requirieron más mantenimiento, tuvieron el mayor porcentaje de individuos requiriendo mantenimiento adicional y árboles a revisar nuevamente. De las especies analizadas, silver maple y honeylocust requirieron el mayor mantenimiento, mientras sugar maple, green ash y littleleaf linden requirieron el menor. A lo largo de todas las clases de daño y especies, los requerimientos de mantenimiento incrementaron con el diámetro del árbol y la altura a nivel del pecho, sin importar el porcentaje de pérdida de copa o la especie. 